\title{
The Effect of Perceived Organizational Support on Work Engage- ment Through Job Crafting (Study At General Division Employees Of Bank Jatim Head Office Surabaya)
}

\author{
Lady Oktafia Alfatekha W \\ Faculty of Economics and Business, State University of Surabaya, Indonesia \\ Email: Lady.17080574061@mhs.unesa.ac.id \\ Budiono \\ Faculty of Economics and Business, State University of Surabaya, Indonesia \\ Email: Ec.budiono@unesa.ac.id
}

\begin{abstract}
PT Bank Pembangunan Daerah Jawa Timur Tbk or Bank Jatim, Bank Jatim was establised on august 17, 1961 in Surabaya. as a BUMD, Bank Jatim is the largest bank in East Java. The goal of this research is to examine and analyze the impact of employee's perceived organizational support on work engagement through job crafting at the General Division in Bank Jatim Surabaya. This study is a causal research of quantitative approach. A total of 56 respondent are used for the sampling technique. With the support of SmartPLS v.3.6.2 software, the statistical analysis used in this research is Partial Least Square (PLS). The analysis outcomes indicate that perceived organizational support has a significant positive effect on work engagement, perceived organizational support has a significant positive effect on job crafting, job crafting has a significant positive effect on work engagement, and job crafting has successfully mediated the effect of perceived organizational support on work engagement.
\end{abstract}

\section{Keywords: Job Crafting, Perceived Organizational Support, Work Engagement}

Received: 27 April 2021;

Accepted: 2 June 2021 ;

Publish: June 2021

\section{How to Cite:}

Alfatekha, L.O., Budiono. (2021). The Effect of Perceived Organizational Support on Work Engagement Through Job Crafting (Study At General Division Employees Of Bank Jatim Head Office Surabaya). Journal of Business and Behavioural Entrepreneurship, 5(1), 109-126. https://doi.org/10.21009/JOBBE.005.1.07 


\section{INTRODUCTION}

Experts agree that the level success of a company is measured by the quality of its human resources. The development of advanced technology is so fast that makes employees are required to be able to recognize their competencies, this is useful to support their performance because it can have a significant impact on the performance of daily tasks (Leni, 2018). A study conducted by Gallup on "The Relationship Between Engagement at Work and Organizational Outcomes" in 2020 explains that a business with the highest level of employee engagement in all businesses contained in the database Gallup has an $83 \%$ chance of having the highest performance above average. This, when compared with the $17 \%$ chance for those with the lowest level of employee involvement (Harter et al., 2020). That research is also supported by Rahman (2016) which states that engagement focuses on ways of working that have an impact on employees (individual results) and the long-term sustainability of the organization. Based on this research, it can be seen if work engagement at the company is a very meaningful matter.

Employees who are involved in their work will feel excited, feel proud of what they are doing, time at work passes quickly and they have a sense of personal satisfaction (Fazlurrahman et al., 2020). There are three factors that can influence work engagement according to Rakhim's research (2020) namely job demands, job resources, and personal resources. This opinion can be understood that the three factors mentioned have something to do with job crafting and the perceptions that employees feel about organizational support. Personal resources refer to behavior job crafting and job resources related to POS.

Job crafting itself is an attitude that can inspire employees to be more dedicated to their work with high attention and energy (Park et al., 2020). This can be interpreted that job crafting has an influence on work engagement (Park et al., 2020). This statement is supported by research from Ogbuanya \& Chukwuedo (2017), Monita (2020), Albana (2018), and Syah (2020) where job crafting has a significant positive effect on work engagement. However, this statement is different from research from Aldrin \& Merdiaty (2019) which states that there is no proven effect of work craft on work engagement.

This proactive attitude is intended to better align work with personal characteristics (Saragih.S et al., 2020). When employees face their work positively, they feel their work is personally meaningful, feel they can manage their workload well, and have a good future (Lely \& Dwiarko, 2020). Thus, POS is considered as one of the factors influencing job crafting because POS encourages employees to be more creative, obtain more resources and change the meaning of their work (Saragih.S et al., 2020). This expression is in line with research by Mallick (2018), and Park et al. (2020) which explains if there is a positive influence between perceived organizational support on job crafting. However, it is inversely proportional to the research of Saragih.S et al., (2020) which states that there is no statistically significant relationship between POS and Job crafting.

Not only job craftingis able to influence work engagement, POS Focusing on a universal belief that the company contributes and ignores the welfare of its employees also affects work engagement (Saragih \& Margaretha, 2013). The POS leads to positive results for work engagement because employees with a large POS allow them to feel enthusiastic and give full dedication to helping achieve organizational goals (Saragih \& Margaretha, 2013). In line with this research, other research that supports the POS statement has a positive influence on work engagement, including research

The Effect of Perceived Organizational Support on Work Engagement Through Job Crafting (Study At General Division Employees Of Bank Jatim Head Office Surabaya). 
from Alfajar (2020), Imran et al. (2020), Showkat (2020), Tan et al. (2020), and Mustika \& Rahardjo (2017). However, in contrast to research from Sulistyo (2017), it has no significant positive results on the effect of perceptions of organizational support on work engagement.

The research results above are in accordance with the phenomenon that occurred at Bank Jatim Surabaya head office which is the object of this research. Bank Jatim Surabaya head office is the largest BUMD in East Java. In managing its employees, Bank Jatim Surabaya revitalizes employees to become superior, independent, competitive and professional employees. Employee competence is improved through the provision of seminars/training/workshops and socialization in accordance with employee needs in order to produce human resources who are able to seek business opportunities and are able to execute well so that employees can provide support in order to achieve the vision and mission of Bank Jatim. Bank Jatim employees are given the same career opportunities in selecting career programs in accordance with the conditions imposed (https://bankjatim.co.id/en, 2021).

A different opinion was conveyed by one of theemployees business partner in thedivision, Human Capital explaining that based on the employee assessment in 2020, especially regarding employee engagement, there are still employees who havestatus dissengaged. The following are the results of employee engagement in 2020 as a whole, namely there are $53 \%$ of employees withstatus actively engaged (employees who contribute fully and have great satisfaction in their work) $25 \%$ withstatus potentially engaged (employees who tend to lower their performance if they are still not satisfied with the organization), $7 \%$ have astatus passively engaged (employees who have not fully contributed to the company's success), and 7\% have astatus disengaged (employees who feel underutilized, and do not get what they need from work). The cause of employees with thestatus disengaged highestis due to the lack of support felt by employees regarding the provision of training from companies that are carried out online due to the pandemic so that employees feel less benefit from the training. However, the $7 \%$ figure has shown a decrease compared to 2019 where $16 \%$ of employees havestatus disenggaged. This shows that Bank Jatim Surabaya Head Office has done a good job of improving the quality of its employees.

Meanwhile, the general division also has several employees whosehas decreased work engagementdue to retirement age and the factor of saturation with their work because they have been working on the same job for too long for many years. However, Bank Jatim continues to improve the quality of employee performance continuously so as to create employees who contribute and are fully committed to the company. The Bank provides support, one of which includes periodic salary evaluations, promotions and transfers if needed, improvement of facilities including health facilities, providing interesting training related to the job desk, and creating creative corner rooms. Everything is intended to create a staffing program that is as current as possible to make it easier for employees to do their jobs.

This research has a purpose to test and analyze the effect of perceived organizational support onvariables work engagement for employees of the General Division of Bank Jatim Surabaya Head Office, test and analyze how the influence of perceived organizational support onvariables for job crafting General Division employees of Bank Jatim Surabaya Head Office, to test and analyze the effect of the job crafting variable on thevariable engagement employeeof the General Division of Bank Jatim Surabaya Head Office, as well as to test and analyze the effect of perceived organizational support on work engagement through job crafting for employees of the General Division of Bank Jatim Surabaya Office Center. Job crafting itself is an attitude that can

The Effect of Perceived Organizational Support on Work Engagement Through Job Crafting (Study At General Division Employees Of Bank Jatim Head Office Surabaya). 
inspire employees to be more dedicated to their work with high attention and energy (Park et al., 2020). This can be interpreted that job crafting has an influence on work engagement (Park et al., 2020). This statement is supported by research from Ogbuanya \& Chukwuedo (2017), Monita (2020), Albana (2018), and Syah (2020) where job crafting has a significant positive effect on work engagement. However, this statement is different from research from Aldrin \& Merdiaty (2019) which states that there is no proven effect of work craft on work engagement.

This proactive attitude is intended to better align work with personal characteristics (Saragih.S et al., 2020). When employees face their work positively, they feel their work is personally meaningful, feel they can manage their workload well, and have a good future (Lely \& Dwiarko, 2020). Thus, POS is considered as one of the factors influencing job crafting because POS encourages employees to be more creative, obtain more resources and change the meaning of their work (Saragih.S et al., 2020). This expression is in line with research by Mallick (2018), and Park et al. (2020) which explains if there is a positive influence between perceived organizational support on job crafting. However, it is inversely proportional to the research of Saragih.S et al., (2020) which states that there is no statistically significant relationship between POS and Job crafting.

Not only job craftingis able to influence work engagement, POS Focusing on a universal belief that the company contributes and ignores the welfare of its employees also affects work engagement (Saragih \& Margaretha, 2013). The POS leads to positive results for work engagement because employees with a large POS allow them to feel enthusiastic and give full dedication to helping achieve organizational goals (Saragih \& Margaretha, 2013). In line with this research, other research that supports the POS statement has a positive influence on work engagement, including research from Alfajar (2020), Imran et al. (2020), Showkat (2020), Tan et al. (2020), and Mustika \& Rahardjo (2017). However, in contrast to research from Sulistyo (2017), it has no significant positive results on the effect of perceptions of organizational support on work engagement.

The research results above are in accordance with the phenomenon that occurred at Bank Jatim Surabaya head office which is the object of this research. Bank Jatim Surabaya head office is the largest BUMD in East Java. In managing its employees, Bank Jatim Surabaya revitalizes employees to become superior, independent, competitive and professional employees. Employee competence is improved through the provision of seminars/training/workshops and socialization in accordance with employee needs in order to produce human resources who are able to seek business opportunities and are able to execute well so that employees can provide support in order to achieve the vision and mission of Bank Jatim. Bank Jatim employees are given the same career opportunities in selecting career programs in accordance with the conditions imposed (https://bankjatim.co.id/en, 2021).

A different opinion was conveyed by one of theemployees business partner in thedivision, Human Capital explaining that based on the employee assessment in 2020, especially regarding employee engagement, there are still employees who havestatus dissengaged. The following are the results of employee engagement in 2020 as a whole, namely there are $53 \%$ of employees withstatus actively engaged (employees who contribute fully and have great satisfaction in their work) $25 \%$ withstatus potentially engaged (employees who tend to lower their performance if they are still not satisfied with the organization), $7 \%$ have astatus passively engaged (employees who have not fully contributed to the company's success), and 7\% have astatus disengaged (employees who feel underutilized, and do not get what they need from work). The

The Effect of Perceived Organizational Support on Work Engagement Through Job Crafting (Study At General Division Employees Of Bank Jatim Head Office Surabaya). 
cause of employees with thestatus disengaged highestis due to the lack of support felt by employees regarding the provision of training from companies that are carried out online due to the pandemic so that employees feel less benefit from the training. However, the 7\% figure has shown a decrease compared to 2019 where $16 \%$ of employees havestatus disenggaged. This shows that Bank Jatim Surabaya Head Office has done a good job of improving the quality of its employees.

Meanwhile, the general division also has several employees whosehas decreased work engagementdue to retirement age and the factor of saturation with their work because they have been working on the same job for too long for many years. However, Bank Jatim continues to improve the quality of employee performance continuously so as to create employees who contribute and are fully committed to the company. The Bank provides support, one of which includes periodic salary evaluations, promotions and transfers if needed, improvement of facilities including health facilities, providing interesting training related to the job desk, and creating creative corner rooms. Everything is intended to create a staffing program that is as current as possible to make it easier for employees to do their jobs.

This research has a purpose to test and analyze the effect of perceived organizational support onvariables work engagement for employees of the General Division of Bank Jatim Surabaya Head Office, test and analyze how the influence of perceived organizational support onvariables for job crafting General Division employees of Bank Jatim Surabaya Head Office, to test and analyze the effect of the job crafting variable on thevariable for work engagement employees of the General Division of Bank Jatim Surabaya Head Office, as well as to test and analyze the effect of perceived organizational support on work engagement through job crafting for employees of the General Division of Bank Jatim Surabaya Office Center.

\section{LITERATURE REVIEW}

\section{Perceived Organizational Support}

Rhoades \& Eisenberger (2002) define organizational support experienced by employees as a whole as a belief about the extent to which the company is able to appreciate the contribution and concern for the welfare of its employees. Afzali et al., (2014) argue that perceived organizational support (POS) basically refers to a reciprocal social exchange relationship between employers and employees, which emphasizes the quality of the relationship. Demir, (2015) argues that organizational support refers to workers' perceptions of whether an organization cares about the welfare and contributions of its employees. Perceived organizational support means the need for social affection, effort, commitment, and individual loyalty recognized by that organization (Hoa et al., 2020). POS according to Stinglhamber et al (2020) is a social exchange process in which employees feel obliged to help the organization achieve its goals and expect their increased performance or efforts on behalf of the organization to be rewarded. POS is also known as an important feature to increase personnel self-initiation and positive behavior for work (Chiang \& Hsieh, 2012).

In Tjandra's research, Hans. et al., (2018) explained that there are 8 indicators used to measure the level of thevariable POS, namely (1) the company is able to appreciate employee contributions, (2) the company is able to appreciate the extra effort that employees have given, (3) the company has paid attention to everything complaints from employees, (4) the company is very concerned about the welfare of employees, (5) the company will notify employees if they do not do a good job, (6) the

The Effect of Perceived Organizational Support on Work Engagement Through Job Crafting (Study At General Division Employees Of Bank Jatim Head Office Surabaya). 
company cares about the general satisfaction of employees' work, (7) the company shows great concern towards employees, and (8) the company feels proud of the success of employees at work.

\section{Job Crafting}

Tims \& Bakker (2010) describe job crafting as an adjustment made by employees in equating work demands and resources according to the needs, abilities, and individual preferences of employees. Job crafting means a process when employees take part in changing the cognitive, social and physical tasks of their work according to Slemp \& Vella-Brodrick (2014). Tims \& Parker (2020) assumes job crafting as an individual-level process driven by individual motives to maintain a positive self-image, increase the meaning of work, or improve one's well-being and performance. Job crafting is rooted in the theory of self-determination, in which autonomous self-regulation creates a link between craft work and fulfillment of needs, namely feelings of value and meaning (Hu et al., 2020). Petrou et al., (2015) define job crafting as the initiative and willingness of employees to reconstruct aspects of their work, with the aim of improving their working conditions. Job crafting is also defined as an effort to change work boundaries, work relationships and the meaning of work for the benefit or convenience of the employees themselves (Kanten, 2014). Work craft describes behavior that involves employees, on their own initiative, where they change aspects of their work and work environment (Demerouti, 2014).

The indicator job crafting in Nguyenresearch et al (2019)'shas 3 indicators, namely task crafting related to modifying tasks given by superiors, relational crafting involving with whom, when and how employees interact with coworkers, and cognitive crafting related to modifying the way employees view of their work.

\section{Work Engagement}

Crawford et al (2010) argue that work engagement is about how an employee exploits themselves in an organizational role by converting their energy into emotional, cognitive and physical work. Work engagement is a motivational concept, because employees allocate personal resources for their work tasks (Decuypere \& Schaufeli, 2020). Truss et al (2011) suggested that work engagement is a positive reaction of employees when carrying out their work, which consists of: willingness to contribute intellectual effort, experience positive emotions and have a meaningful relationship with others. Work engagement is an important feature that emphasizes employee insight into their work regarding how employees pay attention to their work, the end result obtained will increase their creativity and can provide more dynamic results in their workplace (Mubarak \& Noor, 2018).

In Sitorus' research (2018), he defines work engagement as a condition in which a person feels satisfied and thinks positively in his work which is characterized by enthusiasm (vigour) related to the level of enthusiasm and enthusiasm in doing work and facing difficulties, dedication (dedication) related to a sense of pride and enthusiasm. inspired by their work, and high absorption in doing work (absorption) related to employees who drift and find it difficult to break away from their work.

The Effect of Perceived Organizational Support on Work Engagement Through Job Crafting (Study At General Division Employees Of Bank Jatim Head Office Surabaya). 


\section{Relationship Between Variable}

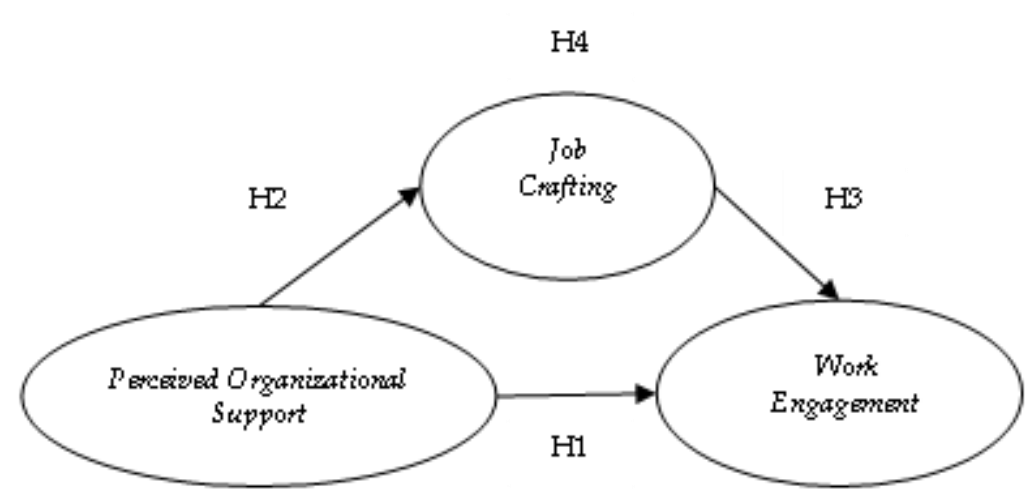

Figure 1 Conceptual Research

Data Processed (2021)

\section{The Effect of Perceived Organizational Support (X) on Work Engagement (Y)}

POS can push companies towards positive results for work engagement because employees with large POS allow them to feel enthusiastic and able to give full dedication to helping achieve organizational goals (Saragih and Margaretha, 2013). Other research that supports POS statements that have a positive influence on work engagement includes research from Alfajar (2020), Imran et al (2020), Showkat (2020), Mufarrikhah et al (2020), Sitorus (2018), A. Dwitasari et al. al (2015), Tan et al (2020), and Mustika \& Rahardjo (2017). However, in contrast to research from (Yulivianto, 2019) and Sulistyo (2017), the results were not significantly positive on the effect of perceptions of organizational support on work engagement.

\section{H1: It is suspected that perceived organizational support has a positive influence on work engagement.}

Positive treatment at work can create positive employee emotions that support employees to carry out positive voluntary behavior (for example, work craft or job crafting) for the organization (Saragih, Susanti. et al, 2020). This is supported by the results of research from (Kim et al., 2017), Mallick (2018), Cheng \& O-Yang (2018), Park et al. (2020), and Zhang \& Zhang (2021), who explained that there was a significant positive effect between perceived organizational support on job crafting. Research conducted by Kim et al., (2018) states that POS has a positive effect on cognitive crafting but has no effect on task crafting and relational crafting. Furthermore, in the study of Saragih.S, et al. (2020) and Kanten (2014) which state that there is no statistically significant relationship between POS and Job crafting.

H2: It is suspected that perceived organizational support positively affects job crafting.

Job crafting is also one of the behaviors that can inspire employees to be more dedicated to their work with increased attention and energy (Park et al., 2020). This means that job crafting has a positive influence on work engagement (Park et al.,

The Effect of Perceived Organizational Support on Work Engagement Through Job Crafting (Study At General Division Employees Of Bank Jatim Head Office Surabaya). 
2020). This statement is supported by research from Ogbuanya \& Chukwuedo (2017), Monita (2020), ALBANA (2018), Frederick \& VanderWeele (2020), Stephani \& Kurniawan (2018), Sharma \& Nambudiri (2020), Azizah \& Ratnaningsih (2018), and Shah (2020) that job crafting has a significant positive effect on work engagement. research from Aldrin and Merdiaty (2019), Setyawati \& Nugrohoseno (2019) and Fazriati \& Budiono (2017) states that there is no proven effect of work craft on work engagement.

\section{H3: It is suspected that job crafting has a positive influence on work engagement.}

When employees view the organization's efforts positively including support for career development, employees will tend to respond by being deeply involved in their work (Showkat, 2020). Employees with high POS are motivated to do better and achieve more (Tan et al., 2020). This is part of the reciprocal norm to assist the organization in achieving its goals (Imran et al., 2020). In addition, POS also plays a role in determining employee attitudes and behaviors such as strengthening cognitive and emotional evaluations of their work (Cheng \& O-Yang, 2018). POS encourages employees to get additional resources by utilizing job crafting (Mallick, 2018). Positive treatment at work can also create positive emotions for employees to carry out positive voluntary behavior (job crafting) for the organization (Saragih, Susanti et al, 2020). In addition, job crafting is also one way that might increase work engagement, namely by involving employees on their own initiative, where they change aspects of their work and work environment (Frederick \& VanderWeele, 2020). The findings of Park et al., (2020) state that when workers feel that their organization supports their work and well -being, their perception of organizational support increases their willingness to find more resources and modify the cognitive boundaries of their work. Thus, the job crafting behavior inspires employees to be more dedicated to their work with increased attention and energy (Park et al., 2020).

\section{H4: It is suspected that job crafting mediates the effect of perceived organization- al support on work engagement}

\section{RESEARCH METHODS}

This research belongs to the type of quantitative research. The research was carried out by the general division of Bank Jatim Surabaya. The head office is located at Jl. Basuki Rahmat No. 98-104. The system for collecting information or data by distributing research questionnaires with answers using a Likert scale from 1 to 5 as a measurement scale, structured and unstructured interviews, and using the results of observations. The study population consisted of general division employees as many as 56 respondents. The sampling technique used saturated samples, which involved the entire number of employees of the general division of Bank Jatim Headquarters with a sample size of 56 samples. This research was supported with the help of SmartPLSsoftware version 3.0as a data analysis technique using Partial Least Square (PLS). 


\section{RESULTS AND DISCUSSION}

Following the description along with information based on the characteristics of the respondent including gender, years of service, and education to support this research. This study has a total sample size of 56 respondents, more specifically for men the number is 28 employees (50\%) and 28 female employees (50\%). Employees with SLTA education are 11 employees $(19.6 \%)$, S1 are 35 employees $(62.5 \%)$, and $\mathrm{S} 2$ are 10 employees (17.9\%). Furthermore, for tenure, as many as 26 employees have worked in a range of $1-5$ years $(46.4 \%), 26$ employees have worked in a range of 6-10 years $(46.4 \%)$, and 4 employees who work in ranges above 10 . years $(7,1 \%)$.

The calculation of the respondents 'average answers was assisted by the three box method in assessing the respondents' answers (mean), where number 1 means the low value and number 5 means the highest value. This the mean description for the POS indicator, namely 4.11 for the first indicator, 3.83 for the second indicator, 3.75 for the third indicator, 3.99 for the fourth indicator, 3.98 for the fifth indicator, as many as 3.91. on the sixth indicator, and as much as 3.84 on the seventh indicator, and 3.87 on the last indicator which is the eighth. The POS variable has a mean of 3.91 which is in the high category. Then, the mean of respondents' answers to the indicators job crafting has a value of 3.77 on the indicator task crafting, 3.98 on the indicator relational crafting, and 3.96 on the indicator cognitive crafting. The variable job crafting itself has a mean of 3.91 which is in the high category. Meanwhile, the indicator work engagement has a value of mean 3.89 on the indicator vigour, a mean of 3.98 on the indicator dedication, as much as 3.81 on the indicator absorption. Work engagement has a mean of 3.89 where the value is high.

\section{Convergent Validity}

Figure 2 shows the results of the validity test per item, showing that all indicators have an outer loading of more than 0.70 . Thus, each indicator has met the requirements and it declared effective or valid due to the value loading the factor is greater than 0.5 .

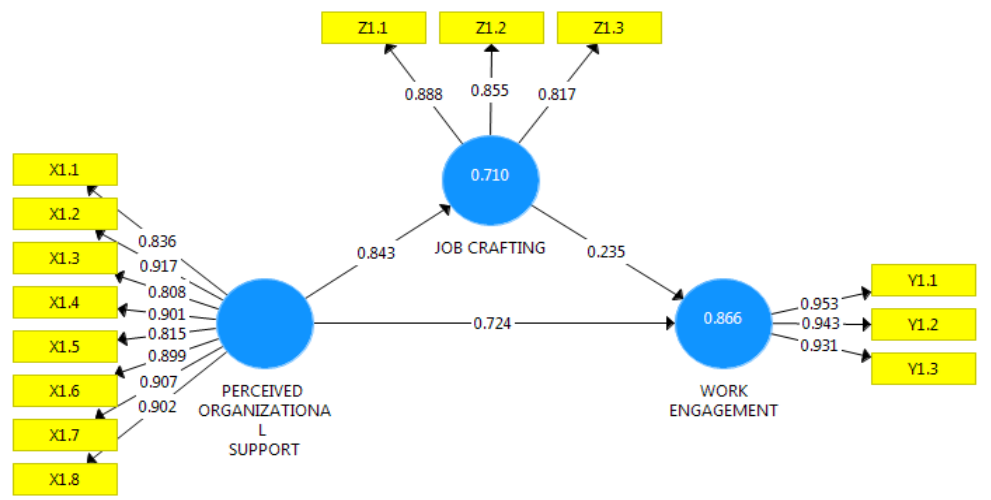

Source: Output of SmartPLS v.3.2.6 (2021)

Figure 2 MEASUREMENT TEST MODEL

\section{Cronbach's Alpha \& Composite Reliability}

The Effect of Perceived Organizational Support on Work Engagement Through Job Crafting (Study At General Division Employees Of Bank Jatim Head Office Surabaya). 
Table 1 shows the reliability test values of the three variables using Cronbach's alpha $\&$ composite reliability. The table shows that the variable POS has a Cronbach's alpha 0.815 and a composite reliability 0.890 , where the value is $>0.70$. This means that the construct / variable has high reliability. The variable job crafting has a cronbach's alpha 0.955 then a composite reliability 0.963 , greater than 0.70 , which means that the variable has high reliability. Work engagement has Cronbach's alpha 0.937 and composite reliability 0.960 , which is greater than 0.7 . This means that these variables have high reliability. The explanation above can be understood that all variables / constructs have excellent composite reliability.

Table 1

CRONBACH'S ALPHA \& COMPOSITE RELIABILITY

\begin{tabular}{|l|c|c|}
\hline & Cronbach's Alpha & Composite Reliability \\
\hline $\begin{array}{l}\text { Perceived organizational } \\
\text { support }\end{array}$ & 0,815 & 0,890 \\
\hline Job crafting & 0,955 & 0,963 \\
\hline Work engagement & 0,937 & 0,960 \\
\hline
\end{tabular}

Source: Output of SmartPLS v.3.2.6 (2021)

\section{R-Square Analysis}

Table 2 shows the value of R Square on the effect of perceived organizational support on job crafting is 0.710 . The value of the construct variable job crafting believed to be able to be explained by $71 \%$ of the variable, perceived organizational support while $29 \%$ of the causes can be interpreted by other variables which are not included in this research. Furthermore, work engagement is influenced by perceived organizational support which has an R Square value of 0.866 which can be interpreted if work engagement can be explained by $87 \%$ of the variables perceived organizational support and $13 \%$ explained by other variables not described in this study

Table 2

R SQUARE

\begin{tabular}{|l|c|}
\hline & R Square \\
\hline Job crafting & 0,710 \\
\hline Work engagement & 0,866 \\
\hline
\end{tabular}

Source: Output of SmartPLS v.3.2.6 (2021)

\section{Causality Test}

Can be seen in table 3, the effect of POS on work engagement has a statistical value of $4.699 \geq 1.96$. Regarding this, explaining if POS has a significant effect on work engagement. In addition, the original sample has a value of 0.721 which means a positive sign and means that high POS action causes work engagement as well, and vice versa.

The Effect of Perceived Organizational Support on Work Engagement Through Job Crafting (Study At General Division Employees Of Bank Jatim Head Office Surabaya). 
Then, the impact of the POS on job crafting got a statistical value of $3,762 \geq$ 1.96. This value shows if the POS has a significant positive effect on job crafting. While the original sample value is positive, which means that the better the POS, the better the job crafting is, and vice versa.

Furthermore, $\mathrm{T}$ statistics on the effect of job crafting on work engagement is $2.145, \geq 1.96$. Regarding that, it can be interpreted if the job crafting positively affects work engagement. Meanwhile, the value of the original sample was 0.235 , meaning that if employees do a good job crafting, the better the work engagement. Likewise about the opposite.

Meanwhile, related to the effect of POS on work engagement through job crafting, it has a T statistic of 2.465, greater than 1.96. This explains if the variable job crafting succeeds in mediating the influence of the POS variable on work engagement.

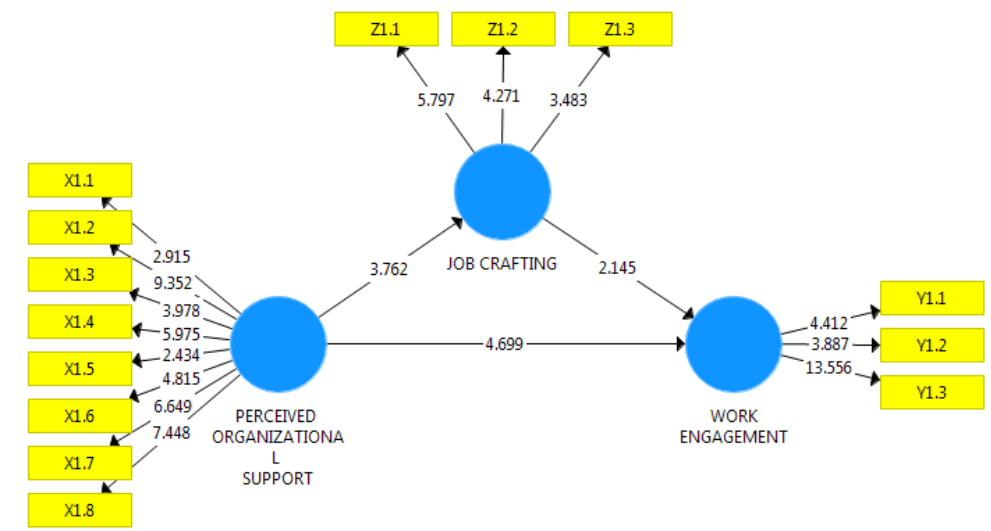

Sources: Output of SmartPLS v.3.6.2 (2021)

Figure 3 MEASUREMENT TEST BOOSTRAPING MODEL

Table 3

PATH COEFFICIENTS \& INDIRECT EFFECT

\begin{tabular}{|c|c|c|l|}
\hline Diagram Path & $\begin{array}{c}\text { Original } \\
\text { Sample }\end{array}$ & $\begin{array}{c}\text { T- } \\
\text { Statistics }\end{array}$ & \multicolumn{1}{|c|}{ Information } \\
\hline $\begin{array}{c}\text { Perceived } \\
\text { organizational support } \\
\rightarrow \text { Work engagement }\end{array}$ & 0,721 & 4,699 & $\begin{array}{l}\geq 1,96 \text { (Significant) } \\
\text { Hypothesis is accepted }\end{array}$ \\
\hline $\begin{array}{c}\text { Perceived } \\
\text { organizational support } \\
\rightarrow \text { Job crafting }\end{array}$ & 0,843 & 3,762 & $\begin{array}{l}\geq 1,96 \text { (Significant) } \\
\text { Hypothesis is accepted }\end{array}$ \\
\hline $\begin{array}{c}\text { Job crafting } \rightarrow \text { Work } \\
\text { engagement }\end{array}$ & 0,235 & 2,145 & $\begin{array}{l}\geq 1,96 \text { (Significant) } \\
\text { Hypothesis is accepted }\end{array}$ \\
\hline $\begin{array}{c}\text { Perceived } \\
\text { organizational support } \\
\rightarrow \text { Job crafting } \rightarrow \text { Work } \\
\text { engagement }\end{array}$ & 0,198 & 2,465 & $\begin{array}{l}\geq 1,96 \text { (Significant) } \\
\text { Hypothesis is accepted }\end{array}$ \\
\hline
\end{tabular}

The Effect of Perceived Organizational Support on Work Engagement Through Job Crafting (Study At General Division Employees Of Bank Jatim Head Office Surabaya). 


\section{The Effect of Perceived Organizational Support on Work Engagement at General Division Employee of Bank Jatim Head Office Surabaya}

The results of the analysis conducted on PLS show that POS has a positive influence on work engagement. From the results of observations and interviews at the general division of Bank Jatim Surabaya Head Office conducted with one of the household staff explained that the leadership has given full trust and support to its employees to handle their respective jobs. In addition, a support program in the form ofhas been implemented rewards. This makes employees feel that they are given trust so that when doing work they become more comfortable, enthusiastic and enthusiastic.

The results of this study are convincing if work engagement affected by perceived organizational support is significantly. That is, the higher the POS, the higher the work engagement. These results are in line with research from Alfajar (2020) which proves that there is a significant positive correlation between POS and work engagement. Research conducted by Imran et al (2020) also shows that when employees feel valued and fully supported by their organization, employees feel a psychological, social, and emotional well-being which then leads them to high dedication to their work.

Furthermore, research from Showkat (2020) also explains that there is a positive relationship between appreciation and recognition, perceived organizational support, work culture and work engagement. In addition, the research of Tan et al (2020), (Saragih and Margaretha, 2013), A. Dwitasari et al (2015), Mufarrikhah et al (2020), Sitorus (2018) and Mustika \& Rahardjo (2017) also proves that POS has a significant and positive influence on work engagement.

\section{The Effect of Perceived Organizational Support on Job Crafting at General Division Employee of Bank Jatim Head Office Surabaya}

Hypothesis testing gives results that show that job crafting is positively influenced by POS. In this case, it means that if the crafting job has a good level, the POS will also be good. This research is in line with research that has been carried out by Mallick (2018), Park et al (2020), (Kim et al., 2017), Cheng \& O-Yang (2018), and research by Zhang \& Zhang (2021) also explains that when If employees have a feeling that they have been supported by the company or superiors, thewill increase job crafting . Research conducted by Kim et al., (2018) states that POS has a positive effect on cognitive crafting but has no effect on task crafting and relational crafting. In contrast to the research of Saragih.S et al., (2020) and Kanten (2014) which state that there is no statistically significant relationship between POS and Job crafting.

If it is associated with the phenomenon of general division employees of Bank Jatim Surabaya Head Office, based on the results of observations and interviews conducted on one of the household sub-division employees explained that all employees have implemented job crafting to modify their work to make it easier to work on. For example, in the print inventory section, there are nominative assignments once a month. So that employees record the nominative every day so that at the end of the month there is no need to write or record the nominative from the beginning again. This shows that employees modify the way they work according to the convenience of employees to make it easier to work. Of course, employees get full support from the company to free their employees from work as long as their actions are in accordance with the rules and regulations imposed by the bank. 


\section{Effect of Job Crafting on Work Engagement at General Division Employee of Bank Jatim Head Office Surabaya}

Based on the results of the PLS hypothesis test, it shows that work engagement is positively influenced by job crafting. This means that the better the level of job crafting, the better the work engagement. As explained by one of the employees of the general division of Bank Jatim Surabaya Headquarters, Employees feel these three indicators are very influential on work engagement, one of which was the working environment such as a friend or co-worker is important in the sustainability work is one which affects the ease of work and passion employee. When you haveco-workers supportive in one division, you can divide your work evenly and don't feel burdened by one of them. By dividing the tasks, it will be more cheerful and enthusiastic in completing the work because the work done is not done alone but is handled by all employees.

The following research results explain thatvariables job crafting have a significant and positive influence on work engagement. The following are research results that support research (Park et al., 2020), Ogbuanya \& Chukwuedo (2017), Monita (2020), ALBANA (2018), Frederick \& VanderWeele (2020), Stephani \& Kurniawan (2018), Sharma \& Nambudiri (2020), Azizah \& Ratnaningsih (2018) and Shah (2020) which state that job crafting has a significant and positive effect on work engagement. While, Research from Setyawati \& Nugrohoseno (2019) states that there is no influence between job crafting on work engagement because the application of job crafting is still not evenly distributed in all parts. The results of this study are supported by research from Aldrin and Merdiaty (2019), and Fazriati and Budiono (2017) which also states that there is no proven effect of work craft on work engagement.

\section{Effect of Perceived Organizational Support through Job Crafting against Work Engagement on employees are encouraged General Division Bank Jatim Surabaya Head Office The}

The results of the PLS analysis show that job crafting is successful in mediating the effect of POS on work engagement. This is supported by research conducted by Showkat (2020) when employees view the organization's efforts positively including support for career development, employees will tend to respond by being deeply involved in their work. This is part of the norm of reciprocity to assist the organization in achieving its goals (Imran et al., 2020). In addition, POS also plays a role in determining employee attitudes and behaviors such as strengthening cognitive and emotional evaluations of their work (Cheng \& O-Yang, 2018). Positive treatment in the workplace can also create positive emotions for employees to carry out positive voluntary behavior (job crafting) for the organization (Saragih, Susanti et al, 2020). In addition, job crafting is also one way that might increase work engagement, namely by involving employees on their own initiative, where they change aspects of their work and work environment (Frederick \& VanderWeele, 2020). Then, research conducted by Park et al (2020) states thatbehavior job crafting that arises because of feelings of support inspires employees to be more dedicated to their work.

The same thing has happened to employees of the general division of Bank Jatim Surabaya Head Office who explained that support from the company or superiors in the form of periodic salary evaluations, improvement of facilities including health facilities, providing interesting training related to their job desks, and creating creative 
corner rooms that will make employees more comfortable at work. In addition, with the support of co-workers and doing tasks or making decisions by oneself also has an influence on comfort and enthusiasm to work for the company. The rewards provided by Bank Jatim have also been very good, so that employees are increasingly motivated to work and become more enthusiastic and enthusiastic. It can be proven by the number of employees who have worked for more than five years, it can be seen that general division employees have good work engagement. However, if you work too long and do the same thing every day, the employee will experience a saturation phase. When employees feel that their performance has decreased or are less enthusiastic when working, one of the methods the bank has taken to prevent its employees from being bored is by doing work rotations, both internal and external mutations.

\section{CONCLUSION}

The results of the analysis in this study indicate that the four hypotheses are accepted, namely (1) perceived organizational support has a significant positive effect work engagement on researchon employees of the general division of Bank Jatim Surabaya Head Office so that $\mathrm{H} 1$ is accepted, (2) perceived organizational support significantly positively influences job crafting. for employees of the general division of Bank Jatim Surabaya Head Office so that H2 is accepted, (3) job crafting has a significant positive effect on work engagement for employees of the general division of Bank Jatim Surabaya Head Office so that H3 is accepted, and (4) job crafting successfully mediates the effect of perceived organizational support for work engagement for employees of the general division of Bank Jatim Surabaya Head Office so that $\mathrm{H} 4$ is accepted.

Recommendations that can be given based on the results of questionnaire analysis, interviews and observations are the need to improve the form of support companythat will be given to employees so that employees feel they have support in their work, one of which is by improving training programs that are deemed less useful because they are only carried out online. Therefore, to meet the indicator that has a lower value than other indicators, namely "the organization has paid attention to complaints from employees" on the POS variable, the training program can be carried out as attractively as possible such as triggering employee activities to be more actively involved in training activities. Themethod blended learning is one of the training that can be applied where this method combines elements of internet information technology with a class system. Training participants can access the material and study it as if they were attending conventional training in general. Materials can be accessed regardless of place or time, making them suitable for employees who have a personal agenda after work. This method is of course followed by a discussion forum to conduct a question and answer session if it is felt that they do not understand the content of the material.

Then, for the POS variable on the indicator "the organization shows great concern for employees" which has a lower average response value than other indicators, that can be done by increasing the provision of facilities for employees with the aim of supporting the convenience and comfort of employees in working so that they can improvebehavior job crafting and work engagement. Examples of facilities that can be applied include providing comfortable work space layout facilities such as changing the layout of the work desk that can affect interaction between employees, improving the quality of work equipment such as computers and other work tools so that employees get the best quality at work. The provision of these facilities can create

The Effect of Perceived Organizational Support on Work Engagement Through Job Crafting (Study At General Division Employees Of Bank Jatim Head Office Surabaya). 
work effectiveness from employees so that employees feel comfortable and the spirit or work engagement itself will increase. Further research is expected to be carried out on the object of BUMN companies so that the research has a wider generalization area and can be developed to be more perfect.

\section{REFERENCES}

Afzali, A., Amir Arash, M., \& Loghman, H.-S. (2014). Investigating The Influence Of Perceived Organizational Support, Psychological Empowerment And Organizational Learning On Job Performance: An Empirical Investigation. The Journal Tehnički Vjesnik, 21(3), 623-629.

Albana, H. (2018). Pengaruh Job Crafting Terhadap Kinerja Karyawan Yang Dimediasi Oleh Work Engagement Di Pt. Terminal Teluk Lamong, Surabaya. Jurnal Ilmu Manajemen (JIM), 7(1), 210-219.

Aldrin, N., \& Merdiaty, N. (2019). Effect of job crafting on work engagement with mindfulness as a mediator. Cogent Psychology, 6(1). https:// doi.org/10.1080/23311908.2019.1684421

Alfajar, N. F. (2020). Hubungan Antara Loyalitas dan Perceived Organizational Support dengan Work Engagement pada Petugas Pelayanan Kantor Ditlantas Polda Daerah X. Jurnal Psikologi, 16(1), 17-24.

Azizah, R., \& Ratnaningsih, I. Z. (2018). Hubungan Antara Job Crafting Dengan Keterikatan Kerja Pada Karyawan Generasi Y Di Kantor Pusat Pt. Bank Bukopin, Tbk Jakarta. Jurnal Empati, 7(2), 167-173.

Bakker, A. B., \& Demerouti, E. (2014). Job Demands-Resources Theory. Work and Wellbeing: A Complete Reference Guide, III, 1-28. https:// doi.org/10.1002/9781118539415.wbwell019

Bankjatim.co.id. (2021). Tentang Bank Jatim. (https://bankjatim.co.id/en, diakses pada tanggal 4 februari 2021).

Caesens, G., Stinglhamber, F., \& Marmier, V. (2016). The curvilinear effect of work engagement on employees' turnover intentions. International Journal of Psychology, 51(2), 150-155. https://doi.org/10.1002/ijop.12131

Cheng, J. C., \& O-Yang, Y. (2018). Hotel employee job crafting, burnout, and satisfaction: The moderating role of perceived organizational support. International Journal of Hospitality Management, 72(January), 78-85. https://doi.org/10.1016/ j.ijhm.2018.01.005

Chiang, C. F., \& Hsieh, T. S. (2012). The impacts of perceived organizational support and psychological empowerment on job performance: The mediating effects of organizational citizenship behavior. International Journal of Hospitality Management, 31(1), 180-190. https://doi.org/10.1016/j.ijhm.2011.04.011

Crawford, E. R., LePine, J. A., \& Rich, B. L. (2010). Linking job demands and resources to employee engagement and burnout: A theoretical extension and metaanalytic test. Journal of Applied Psychology, 95(5), 834-848. https:// doi.org/10.1037/a0019364

Decuypere, A., \& Schaufeli, W. (2020). Leadership and work engagement: Exploring explanatory mechanisms. German Journal of Human Resource Management, 34 (1), 69-95. https://doi.org/10.1177/2397002219892197

Demir, K. (2015). The Effect of Organizational Justice and Perceived Organizational Support on Organizational Citizenship Behaviors: The Mediating Role of Organizational Identification. Egitim Arastirmalari - Eurasian Journal of Educational 
Research, 60, 131-148. https://doi.org/10.14689/ejer.2015.60.8

Dwitasari, A. I., Ilhamuddin, I., \& Widyasari, S. D. (2015). Pengaruh Perceived Organizational Support dan Organizational-Based Self Esteem Terhadap Work Engangement. Jurnal Mediapsi, 01(01), 40-50. https://doi.org/10.21776/ ub.mps.2015.001.01.5

Fazlurrahman, H., Wijayati, D. T., Hadi, H. K., Rahman, Z., Nugrohoseno, D., \& Rahman, M. F. W. (2020). Analysis of work engagement measurement at work from home due to the effect of Covid-19 pandemic. Technium Social Sciences Journal, 14, 363-375. www.techniumscience.com

Fazriati, N. F., \& Budiono. (2017). Pengaruh Job Crafting Terhadap Work Engagement Yang Dimediasi Oleh Person Job Fit Pada Pt. Berlian Jasa Teminal Indonesia. Jurnal Ilmu Manajemen (JIM), 5(3), 1-9.

Frederick, D. E., \& VanderWeele, T. J. (2020). Longitudinal meta-analysis of job crafting shows positive association with work engagement. Cogent Psychology, 7 (1). https://doi.org/10.1080/23311908.2020.1746733

Harter, J. K., Schmidt, F. L., Killham, E. A., \& Asplund, J. W. (2020). The Relationship Between Engagement at Work and Organizational Outcomes. Gallup.Inc, (http://strengths.gallup.com/private/resources/q12meta-analysis_flyer_gen_08 08 bp.pdf, diakses pada 4 Februari 2021)

Hoa, N. D., Ngan, P. T. H., Quang, N. M., Thanh, V. B., \& Quyen, H. V. T. (2020). An empirical study of perceived organizational support and affective commitment in the logistics industry. Journal of A sian Finance, Economics and Business, 7(8), 589-598. https://doi.org/10.13106/JAFEB.2020.VOL7.NO8.589

Hu, Q., Taris, T. W., Dollard, M. F., \& Schaufeli, W. B. (2020). An exploration of the component validity of job crafting. European Journal of Work and Organizational Psychology, 29(5), 776-793. https://doi.org/10.1080/1359432X.2020.1756262

Imran, M. Y., Elahi, N. S., Abid, G., Ashfaq, F., \& Ilyas, S. (2020). Impact of perceived organizational support on work engagement: Mediating mechanism of thriving and flourishing. Journal of Open Innovation: Technology, Market, and Complexity, 6(3). https://doi.org/10.3390/JOITMC6030082

Kanten, P. (2014). The antecedents of job crafting: perceived organizational support, job characteristics and self-efficacy. European Journal of Business and Social Sciences, 3(5), 113-128.

Kim, H., Im, J., \& Qu, H. (2018). Exploring antecedents and consequences of job crafting. International Journal of Hospitality Management, 75(February), 18-26. https://doi.org/10.1016/j.ijhm.2018.02.014

Kim, H., Im, J., Qu, H., \& NamKoong, J. (2017). Antecedent and consequences of job crafting: an organizational level approach. International Journal of Contemporary Hospitality Management, 30(3), 1863-1881. https://doi.org/10.1108/ EUM0000000001079

Lely \& Dwiarko. (2020). Peran kompetensi diri antara job enlargement terhadap job crafting. Jurnal Ilmu Manajemen, 8(1), 140-148.

Leni, R. (2018). Pengaruh Era Revolusi Industri 4.0 terhadap Kompetensi Sumber Daya Manusia. Jurnal Manajemen Bisnis Indonesia, 6(1).

Mallick, M. (2018). Exploring antecedents and outcomes of job crafting, Indication from Pakistan International Airline. Journal of Management \& Human Resource Voume-1, 1(December 2018), 18-40.

Monita, Y. (2020). Pengaruh Job Crafting terhadap Keterikatan Kerja dan Kepuasan Kerja pada Karyawan PT . Perta Arun. Jurnal Ilmiah Mahasiswa Ekonomi Manajemen, 5(3), 517-529.

The Effect of Perceived Organizational Support on Work Engagement Through Job Crafting (Study At General Division Employees Of Bank Jatim Head Office Surabaya). 
Mubarak, F., \& Noor, A. (2018). Effect of authentic leadership on employee creativity in project-based organizations with the mediating roles of work engagement and psychological empowerment. Journal Cogent Business and Management, 5(1). https://doi.org/10.1080/23311975.2018.1429348

Mufarrikhah, J. L., Yuniardi, M. S., \& Syakarofath, N. A. (2020). Peran Perceived Organizational Support terhadap Work Engagement Karyawan. Gadjah Mada Journal of Psychology, 6(2), 151-164. https://doi.org/10.22146/gamajop.56396

Mustika, S., \& Rahardjo, K. (2017). Pengaruh Perceived Organizational Support terhadap Employee Engagement dan Organizational Citizenship Behaviour. Jurnal Administrasi Bisnis S1 Universitas Brawijaya, 47(1), 9-15.

Nguyen, H. M., Nguyen, C., Ngo, T. T., \& Nguyen, L. V. (2019). The effects of job crafting on work engagement and work performance: A study of Vietnamese commercial banks. Journal of A sian Finance, Economics and Business, 6(2), 189201. https://doi.org/10.13106/jafeb.2019.vol6.no2.189

Ogbuanya, T. C., \& Chukwuedo, S. O. (2017). Job crafting-satisfaction relationship in electrical/electronic technology education programme: Do work engagement and commitment matter? Journal of Work and Organizational Psychology, 33(3), 9. https://doi.org/10.1016/j.rpto.2017.09.003

Park, Y., Lim, D. H., Kim, W., \& Kang, H. (2020). Organizational support and adaptive performance: The revolving structural relationships between job crafting, work engagement, and adaptive performance. Journal Sustainability (Switzerland), 12(12). https://doi.org/10.3390/SU12124872

Petrou, P., Demerouti, E., \& Schaufeli, W. B. (2015). Job crafting in changing organizations: Antecedents and implications for exhaustion and performance. Journal of Occupational Health Psychology, 20(4), 470-480. https://doi.org/10.1037/ a0039003

Rahman, Z. (2016). Work Engagement : Sequential Model of Internal. The Third International Conference on Entrepreneurship, 2004, 196-205.

Rakhim, A. F. (2020). Factors That Cause Work Engagement in the Millennial Performance in BUMN: Faktor- Faktor Penyebab Work Engagement pada Angkatan Kerja Millennial di BUMN. Proceeding of The ICECRS: Educational and Psychological Conference in the 4.0 Era, 8, 1-8.

Rhoades, L., \& Eisenberger, R. (2002). Perceived organizational support: A review of the literature. Journal of Applied Psychology, 87(4), 698-714. https:// doi.org/10.1037/0021-9010.87.4.698

Saragih, Susanti. Margaretha. Meily, Situmorang. Alando, P. (2020). Analyzing antecedents and consequence of job crafting. International Journal of Management, Economics and Social Sciences (IJMESS), 9(2), 76-89. https://doi.org/10.32327/ IJMESS.9.2.2020.5

Saragih, S., \& Margaretha, M. (2013). Anteseden dan konsekuensi employee engagement: Studi pada Industri Perbankan. Seminar Nasional Dan Call for Paper, Universitas Kristen Maranatha, 1-22.

Setyawati, S. M., \& Nugrohoseno, D. (2019). Praktik sdm, job crafting dan work engagement terhadap kinerja karyawan. Jurnal Ilmu Manajemen (JIM), 7(3), 619628. https://core.ac.uk/download/pdf/230764728.pdf

Sharma, A., \& Nambudiri, R. (2020). Work engagement, job crafting and innovativeness in the Indian IT industry. Personnel Review, 49(7), 1381-1397. https:// doi.org/10.1108/PR-11-2019-0607

Showkat, S. (2020). Impact of Rewards and Recognition , Perceived Organizational Support and Work Culture on Employee Engagement in the Indian IT Industry.

The Effect of Perceived Organizational Support on Work Engagement Through Job Crafting (Study At General Division Employees Of Bank Jatim Head Office Surabaya). 
International Journal of Advanced Science and Technology, 29(02), 3200-3212.

Sitorus, F. (2018). The Influence of Perceived Organizational Support and Internal Communication toward Work Engagement. Proceedings of the 2nd International Conference on Social and Political Development (ICOSOP 2017), 136(Icosop 2017), 280-287. https://doi.org/10.2991/icosop-17.2018.44

Slemp, G. R., \& Vella-Brodrick, D. A. (2014). Optimising Employee Mental Health: The Relationship Between Intrinsic Need Satisfaction, Job Crafting, and Employee Well-Being. Journal of Happiness Studies, 15(4), 957-977. https:// doi.org/10.1007/s10902-013-9458-3

Stephani, D., \& Kurniawan, J. E. (2018). Hubungan Antara Job Crafting dan Work Engagement Pada Karyawan. Psychopreneur Journal, 2(1), 30-40.

Stinglhamber, F., Ohana, M., Caesens, G., \& Meyer, M. (2020). Perceived organizational support: the interactive role of coworkers' perceptions and employees' voice. Employee Relations: The International Journal, 42(1), 107-124. https:// doi.org/10.1108/ER-05-2018-0137

Sulistyo, A. (2017). Pengaruh Karakteristik Pekerjaan, Persepsi Dukungan Organisasi, dan Efikasi Diri Terhadap Kepuasan Kerja Dengan Keterikatan Kerja sebagai Variabel Intervening di Pusat Pengembangan dan Pemberdayaan Pendidik dan Tenaga Kependidikan Bidang Seni dan Budaya Y. Universitas Islam Indonesia. https://dspace.uii.ac.id/handle/123456789/5340

Syah, N. D. (2020). Pengaruh job crafting terhadap work engagement melalui psychological meaningfulness karyawan pt. boma bisma indra (persero) surabaya. Jurnal Ilmu Manajemen, 8(2018).

Tan, L., Wang, Y., Qian, W., \& Lu, H. (2020). Leader Humor and Employee Job Crafting: The Role of Employee-Perceived Organizational Support and Work Engagement. Journal Frontiers in Psychology, 11(October), 1-14. https:// doi.org/10.3389/fpsyg.2020.499849

Tims, M., \& Bakker, A. B. (2010). Job crafting: Towards a new model of individual job redesign. SA Journal of Industrial Psychology, 36(2), 12-21. https:// doi.org/10.4102/sajip.v36i2.841

Tims, M., \& Parker, S. K. (2020). How coworkers attribute, react to, and shape job crafting. SAGE Journals, 10(1), 29-54. https:// doi.org/10.1177/2041386619896087

Tjandra, Hans. Wijaya, Agus. Thio, S. (2018). Pengaruh Perceived Organizational Support Terhadap Komitmen Afektif Karyawan Hotel di Surabaya. Jurnal Hospitality Dan Manajemen Jasa, 6(2). http://publication.petra.ac.id/index.php/ manajemen-perhotelan/article/view/7530

Truss, K., Soane, E., Delbridge, R., Alfes, K., Shantz, A., \& Petrov, G. (2011). Employee engagement, organisational performance and individual well-being: exploring the evidence, developing the theory. The International Journal of Human Resource Management, 22(1), 232-233. https:// doi.org/10.1080/09585192.2011.552282

Yulivianto, T. S. (2019). Job Crafting Dan Persepsi Dukungan Organisasi Terhadap Kinerja Karyawan Melalui Keterikataerja. Jurnal Ilmu Manajemen (JIM), 7(4), 1017-1028.

Zhang, S., \& Zhang, W. (2021). A Serial Mediation Model of Perceived Organizational Support on Turnover Intention: The Role of Job Crafting and Thriving at Work. International Journal of Human Resource Studies, 11(1), 146. https:// doi.org/10.5296/ijhrs.v11i1.18078

The Effect of Perceived Organizational Support on Work Engagement Through Job Crafting (Study At General Division Employees Of Bank Jatim Head Office Surabaya). 